\title{
Celebrating Diversity of Humanity, Struggling for Peace, and Establishing Culture of Coexistence
}

\author{
Hakan Çoruh \\ Charles Sturt University, Victoria, Australia
}

\begin{abstract}
The Qur'an embraces cultural pluralism, emphasising that "People, We created you all from a single man and a single woman, and made you into races and tribes so that you should recognize one another." (Q. 49: 13). Moreover, peace is the most fundamental value in the Qur'an and Islam. The majority of the classical Muslim jurists, especially Hanafĩ school, emphasised that the reason for Muslims' fight against non-Muslims is Muslims' defense themselves against attacks, not non-Muslims' faith. Bediuzzaman Said Nursi (d. 1960) states that the only kind of jihad that is appropriate for the present age is spiritual or moral jihad. Furthermore, regarding Qur'anic approach to relations between Muslims and the People of the Book, Muslim scholars, in general, advocate sincere relations and trust between Muslims and the People of the Book. In addition, Said Nursi is one of the great Muslim scholars in interfaith dialogue in the 20th century. Finally, there is the need for establishing culture of coexistence, which practised before within a religious tradition such as Islamic tradition for many centuries in the history. Through achieving a culture of coexistence and peace, most conflicts can be resolved.
\end{abstract}

Keywords: the Qur'an, pluralism, peace and war, Jihad in the modern period, relations between Muslims and the People of the Book, interfaith dialogue, Bediuzzaman Said Nursi, culture of coexistence in Islamic tradition

\section{Introduction}

It is important to note Muslim scholarship regarding the Qur'anic text and the Prophetic traditions has generally embraced social and cultural pluralism, which seeks to ensure the harmonious coexistence of diverse religious communities and protects the rights and freedoms of the followers of all religions (Albayrak, 2008, p. 318). In this context, the Qur'an indicates the reality of diversity of humanity, and the Qur'an seems germane to cultural and social plurality. A number of Qur'anic verses express these notions. For example, Q. 5: 48 emphasises that "If God had so willed, He would have made you one community, but He wanted to test you through that which He has given you, so race to do good: You will all return to God and He will make clear to you the matters you differed about." According to Fazlur Rahman (d. 1988), the Qur'an gives its final response to the problem of pluralism in verse 5: 48. Briefly, humankind was a single unity, but this unity was later split up in accordance with God's plan. Therefore the Muslim community is recognised as one among the several communities (Albayrak, 2008, p. 320).

Another important verse in relation to plurality is Q. 49 : 13, "People, We created you all from a single man and a single woman, and made you into races and tribes so that you should recognize one another. In

Hakan Çoruh, Ph.D., lecturer, Charles Sturt University.

Correspondence concerning this article should be addressed to 250 Hume Hwy, 3062 Somerton Victoria, Australia. E-mail: hcoruh@csu.edu.au. 
God's eyes, the most honoured of you are the ones most mindful of Him: God is all knowing, all aware." It should be noted that one of the crucial words of the Qur'an regarding plurality lies in this verse. We should reconsider Ta 'aruf (knowing each other) in the context of the need to find common grounds for the coexistence of diverse religious communities. This concept provides a key that could open the door to interfaith dialogue. Here the Qur'an points out equality in regard to biology and a dignity common to all people. Therefore nobody is explained in boasting of an inherent superiority over others (Albayrak, 2008, p. 324). In this context, it is worth mentioning that in the life of the Prophet Muhammad, the tribe of the Quraysh considered themselves and Arabs as being superior to all other people. The Prophet came with this message above and declared that: "No Arab is superior to a non-Arab, and no white person is superior to a black person." (Hanbal, al-Musnad, (Beirut), 5: 441, cited in Ünal, 2008, p. 1056). It is clear that Islamic teaching emphasises that superiority is not related to birth or color, but it is connected with to be mindful of God and devotion to God. At this point, Q. 30 : 22 also underlines that "another of His signs is the creation of the heavens and earth, and the diversity of your languages and colours. There truly are signs in this for those who know."

With regard to pluralism, Q. 2: 62 is one of the most important and controversial verses in relation to religious pluralism. The verse runs as follows: "The [Muslim] believers, the Jews, the Christians, and the Sabians - all those who believe in God and the Last Day and do good - will have their rewards with their Lord. No fear for them, nor will they grieve." While mainstream traditional understanding emphasises that belief in the Prophet Muhammad and follow his way is compulsary for eternal salvation (DİB, 2007, I/136), certain Muslim scholars from the classical and modern period thought differently. For example, Fazlur Rahman believes that the vast majority of Muslim exegetes of the Qur'an avoid giving the obvious meaning of the verses (2: 62; 5: 69) which ensure that whoever (no matter whether they are Muslims, Jews, Christians, or Sabeans) believe in God, and the Last Day, and do good deeds will be saved (Albayrak, 2008, p. 320). To take another example, regarding "But they are not all alike. There are some among the People of the Book who are upright, who recite God's revelations during the night, who bow down in worship," (Q. 3: 113), Muhammad "Abduh (d. 1323/1905) and his favourite disciple, Muhammad Rashid Rida (d. 1354/1935) argue that the classical exegetes failed to understand how a non-Muslim could be saved even if he believes in the basic principles of religion (belief in God, and the Hereafter, and do good deeds), and thus the generality of scholars recognised these praised Jews and Christians in the verse with the converted Muslims (Albayrak, 2008, p. 319). Among the contemporary Muslim scholars, there are certain scholars who support this approach. For example, Mahmoud Ayoub, from Hartford Seminary, believes that the original demand that the Qur'an made of Jews and Christians is simply to accept Muhammad as a prophet and Islam as an authentic religion without necessarily having to give up their faith (Ayoub, 2007). Abdulaziz Sachedina is also one of the proponents of religious pluralism.

In relation to this topic, it is important to look at the Qur'an and Islam's approach to peace and war and their approach to other religious communities. The reason for this is that today we can see certain events that may contradict our argument above.

\section{Peace and War in the Qur'an}

Peace is the most fundamental value in the Qur'an and Islam. The Qur'an states that "You who believe, enter wholeheartedly into peace (submission to God) and do not follow in Satan's footsteps, for he is your sworn enemy." (Q. 2: 208). Moreover, Peace (Salām) is one of the names of God, and it is seen as a 
fundamental part of God's creation and given a significant value (Kalin, 2013, pp. 221, 224-226). It is important to note that the concept of peace is primarily connected with Arabic verbal nouns derived from the root S-L-M (base form: salimalyaslamu). The main nouns from this base form are salamah, salm \& silm, and salam. In classical Arabic the term salm "peacemaking" provides the opposite of war. The semantic scope of several other verbal roots such as sulh (conciliation and peacemaking) and amn, aman and amanah, (safety security - assurance of peace) overlap with the meaning of peace in Islamic tradition. Iman also means "faith, secure belief (safeguarding from perdition)". Verb amina represents providing assurance of safety and security to a person, and expresses protection from harm and injury. Demonstrating security is a mark of reliable trustworthiness, and it is itself considered to be a distinguishing feature of faith iman. In addition, the exchange of greetings, saluting one another with al-Salamu 'alaykum! and its response wa 'alaykum al-salam! are important characteristics of Muslims in their daily life. They are frequently expressed on the lips of Muslims and translated as "Peace be upon you!" and "And upon you Peace!". Here salam is normally understood today as "peace", while its sense might better be provided: "greetings of security-peace". A parallel use of this famous greeting occurs at the very conclusion of Islam's daily ritual prayer with the double salutation of Taslim. After each of the five daily prayers, it is recommended for Muslims to affirm God as the ultimate source and origin of all peace. 'O God, You are Peace-Security (al-Salam), You are the Source of Peace, and Peace properly belongs to You. So greet us Lord with the salutation 'Peace!' (Crow, 2013, pp. 252-258). Then it is concluded that the concept of peace is one of the most fundamental values in Islam, and peace is an inseparable part of Islamic experience.

War is also a situation among different communities throughout the history, and there are several Qur'anic verses regarding war. The concept of jihad is one of the central terms in the Qur'an, and it is often discussed in the context of war. However, jihad is a very comprehensive and dynamic term that takes on different forms, depends on historical occasions and the needs of Muslims. Linguistically jihad means doing one's best, struggling against every kind of difficulty. Religiously, it refers to the struggles one faces for the sake of God. Actually, the Qur'anic verses about war are mostly expressed by the word qital (fighting) rather than jihad (Kurucan, 2013; Heck, 2004, pp. 95-128).

It is important to note that while linguistically jihad has a number of meanings, the majority of the classical Muslim jurists, especially Hanafĩ school, argued that the reason for Muslims' fight, one of the aspects of jihad, against non-Muslims is Muslims' defense themselves against attacks, not non-Muslims' faith. Therefore, it is reasonably concluded that fighting until bringing the world under the reign of Islam by military means and territorial expansion is not related to the concept of jihad and war in Islam. Thus certain verses that may have different implications regarding war need to be analysed deeply by taking their contexts into account (Özel, 1993, pp. 527-531). In other words, the Muslim community has a right to defend itself against internal or external aggression, and certain verses express this reality. For example, Q. 22: 38-40 state that,

God will defend the believers; God does not love the unfaithful or the ungrateful. Those who have been attacked are permitted to take up arms because they have been wronged - God has the power to help them - those who have been driven unjustly from their homes only for saying, "Our Lord is God." If God did not repel some people by means of others, many monasteries, churches, synagogues, and mosques, where God's name is much invoked, would have been destroyed. God is sure to help those who help His cause - God is strong and mighty-.

This and other verses (Al-Baqarah, 2:190-3) define clearly the reasons for taking up arms in order to defend religious freedom and set the conditions of just war in self-defence. That the verse, revealed in the first 
year of the migration, refers to the grave wrongdoing against Muslims and their eviction from their homeland because of professing the new faith confirms that the migration of the Prophet was the last stage of the forceful ejection of the Muslim community from Mecca. This was a turning point for the attitudes and following tactics of the Prophet and his followers to protect themselves against the Meccans. It should be emphasised that the later battles fought between the Meccans and the Medinans, from Badr to Handak until the Prophet's triumphant return to Mecca were based on the same principles of religious freedom, collective solidarity, and political unity. In addition to declaring the conditions of just war, the above verse defines religious freedom as a universal cause for all the three Abrahamic faiths. Like any other political unit, religious communities have the right and the responsibility of protecting their existence and integrity against the threats of persecution and eventual destruction. This ecumenical attitude towards the religious freedom of all faith communities became a major element in the Prophet's signing of a number of agreements with the Jews, Christians and Zoroastrians of the Arabian Peninsula as well as the treatment of religious minorities under the shari'ah (Kalin, 2013, pp. 232-234).

At this point, it is interesting to note that Fazlur Rahman, in his book Major Themes of the Qur'an, explains the true meaning of "Islam was spread by the sword". He states that "what was spread by the sword was the political domain of Islam, not the religion of Islam. Through political domain, Islam could work to produce the order on the earth that the Qur'an seeks. Rahman also believes that "armed jihad was often used by later Muslims whose primary aim was territorial expansion and not the worldview they were asked to establish by God." (Rahman, 2009, p. 63; Kurucan, 2013). Rahman here implies that there had been wars for territorial expansion, political power, and economic benefits. However, the greater Muslim community unaccepted their reasons behind their actions (Kurucan, 2013). Moreover, bringing the territories under the reign of Dar al-Islam by military means and territorial expansion should be seen within the context of the geo-political conditions of the classical Islamic world. The medieval imperial world order was based on the idea of continuously expanding one's borders since "conquest" (fat h) provided economic, political and demographic stability. In this sense, Muslim states were a part of this world order. In a world in which one state was either a "conqueror" or "conquered", the victorious Muslim states relied heavily on the expansion of their territories against both their Muslim opponents and non-Muslim enemies. The historic progress of Muslim armies into territories once under non-Muslim rule was not jihad in the religious sense of the term, but it was a result of the power struggle to which all political establishments, Muslim or non-Muslim, were subject (Kalin, 2013, p. 235) .

In addition, it is worth mentioning that territorial expansion and military conquest did not always and necessarily mean conversion. From the early history of Islam, a great number of methods have been used in order to make the conversion possible through peaceful means. The Muslim scholars or the rulers did not impose conversion by force as a policy. Conversion was not necessary to become part of the Muslim community to have religious freedom, receive protection, and possess property under the Islamic law because of the concept of the dhimmi status for non-Muslims. The dhimmi status (Nielsen, 2003) allowed religious minorities to maintain their traditions. Because Islam does not appoint a missionary establishment, the agents of conversion responsible for the extremely successful spread of Islam were many different types and included from the Arab traders and the Sufis to the development of Islamic communal institutions. It cannot be explained the conversion of numerous ethnic, religious and cultural communities to Islam by the military ability of a handful of Muslim groups in Anatolia, Iran, Africa or India (Kalin, 2013, pp. 235-236). 
In the modern period, the concept of jihad is also one of the main discussions in modern Muslim Qur'an interpretation. J.M.S. Baljon states that the modernist Muslim thinkers are trying to mitigate the jihad doctrine as much as possible. One is warned not to comprehend it as a fight for war-booty, or acquiring dominion. For Muslim modernity, the most favorite verse is Q. 2:256: "There is no compulsion in religion". Moreover, it is emphasized that the believer's total life is jihad to bring his human quality and spirit on an higher level (Baljon, 1961, pp. 108-109). In this context, it is good to indicate Nursi's approach to the notion of jihad because of his influence on many modern Muslims.

Regarding the concept of jihad, Nursi states that "whatever physical jihad demands, we are not charged with that duty at the moment." In his view, the only kind of jihad that is appropriate for the present age is spiritual or moral jihad (Turner, 2013, pp. 557, 563). The way of the Risale-i Nur and its students is service to belief and the Qur'an by peaceful means and "positive action". It is peaceful struggle, a "moral jihad" or "jihad of the word", in the face of the moral and spiritual destructions of atheism and unbelief (Vahide, 2005, p. 307). As we have seen, while Nursi does not reject physical jihad in classical period, he puts emphasis on "spiritual or moral jihad" because of the modern context in Turkey. The reason for his approach is that as a secure state, the Turkish Republic was no longer considered to be coextensive with the "sphere of Islam". After the establishment of the Turkish Republic, Nursi also became aware of the fact that Islam and the state were no longer coextensive; therefore, an attack on "the sphere of Islam" in the territorial sense was meaningless, since there was no sphere of Islam to attack. In his view, the sphere of Islam was no longer a physical state, but rather a state of mind (Turner, 2013, pp. 566-567). In addition, Nursi did not aim at political Islam. Nursi's focus was not on the creation of an ideal socio-political system. He was not one given to "dreaming of Medina". Nursi focused on the principles of belief, and principles which were under attack in his time. When it was Mecca that the Muslim world needed, he emphasized matters of faith, spirituality, and the development of self-knowledge and Divine gnosis. Nursi's stress on the need to safeguard and perfect belief, his withdrawal from politics, his rejection of militant jihad and his gradualist approach to social reform have affected a large number of Muslims in the modern period (Turner, 2013, p. 570).

With regard to the theme of this paper, Qur'anic approach to relations between Muslims and the People of the Book and Muslim behaviour towards Jews and Christians should be scrutinised.

\section{Relations Between Muslims and the People of the Book in the Qur'an}

The Qur'an employs some positive expressions regarding the People of the Book in various places, but it also sometimes seems to have a negative view of them in some respects (Çoruh, 2012, pp. 505-513). For example, according to the Qur'an, those who are the closest in affection to Muslims are Christians. It says: "You are sure to find that the closest in affection towards the believers are those who say, 'We are Christians,' for there are among them people devoted to learning and ascetics. These people are not given to arrogance." (Q. 5: 82). In addition, the Qur'an provides an opportunity to establish the best relationship with the People of the Book by allowing Muslim men to marry Christian and Jewish women, and also to eat their food and the animals that they sacrifice (Q. 5: 5). Furthermore, in the Qur'an, God states that He will make those who follow Jesus superior to those who disbelieve until the day of Resurrection (Q. 3: 55).

Sometimes it presents negative aspects of the People of the Book, as well as criticizing them in some respects. It is important to note that some Qur'anic verses, particularly those that related to Muslim behaviour towards Jews and Christians, require further analysis and a deeper approach. In this context, A. Saeed 
emphasises that when the Qur'an criticizes a Jewish, Christian or even Muslim community, it has been understood by Muslim exegetes (Companions of the prophet and the earliest scholars) as referring to the specific conduct of certain individuals or groups belonging to the community concerned. In order for these verses to be understood, the passages must be read in a highly nuanced way, as well as with an understanding of their specific contexts (Saeed, 2008, pp. 69-70). Moreover, these verses must be seen in the context of the overall qur'anic message and the process of revelation. The occasions of revelation of these verses should be known so that their context and underlying message can be ascertained, and they should be interpreted after consideration of the social and political circumstances of that time (Y1lmaz, 2008, pp. 137-145).

Furthermore, the Companions of the Prophet and the successors agree that the criticism and warnings that the Qur'an expressed because of the particular qualities of some Christians, Jews and the hypocrites, such as hostility and betrayal, can also be applied to Muslims who have these qualities (Gülen, 2014). We can find this idea in the classical exegetical sources. For example, Fakhr al-Dīn al-Rāzī (d. 606/1209) interprets Q 2. 204, concerning some Meccan pagans, in his exegesis and emphasises that this verse applies to all people who have the same qualities. He also states that the majority of the exegetes choose this interpretation (al-Rāzī, 1981, $5 / 214$ ). In addition, Bediuzzaman Said Nursi states that "Just as not all of the characteristics of an individual Muslim necessarily reflect the teaching of Islam, so also, not all of the qualities of individual Jews or Christians reflect unbelief." He also asks the question: "Can a Muslim love a Christian or Jew?" After indicating the marriage of a Muslim man with a woman of the People of the Book, he replies, "Of course, yes. He should love her." (Said Nursi, cited in Albayrak, 2008, pp. 317-318; See also Q. 60:8).

Taking into account all the information above, it can be concluded that, in general, Muslim scholars do not see any obstacle to sincere relations and trust between Muslims and the People of the Book.

\section{Said Nursi and Muslim-Christian Co-operation}

Said Nursi is a muslim thinker and scholar in the 20th century, and his magnum opus the Risale-i Nur Collection is one of the most influential books in the world. The number of literature about Nursi and the Risale-i Nur has been increasing significantly in recent times. Numerous books have been written regarding Nursi and some specific themes of the Risale-i Nur such as theodicy and justice. Prof. Thomas Michel, S.J., at Georgetown Univ., and Prof. Ian S. Markham, the dean and president of Virginia Theological Seminary, studied on Nursi's approach to interfaith dialogue. They put emphasis on that Nursi is one of the great Muslim scholars in interfaith dialogue between Muslims and Christians in 20th century (Michel, 2003; Markham 2009). Markham's argument in his book is that every religious tradition needs a Said Nursi, and Nursi is the future of interfaith dialogue (Michel, 2003; Markham 2009, pp. 145, 175).

Firstly, Nursi finds religious basis for Muslim-Christian cooperation. He recognises that at the end of the age in the cosmic battle against the Dajjäl (the Antichrist, the promotion of naturalist and materialist philosophy, which will cause the total denial of God), there will be a group of sincere Christians who will work with the Muslims to defeat Dajjäl. This cooperation, towards the end of the time, is also linked to the return of Jesus in Nursi's writings (Michel, 2003; Markham 2009, p. 60). It is worth mentioning that Jesus Christ plays a major role in Islamic eschatology. According to the Prophetic tradition (hadith), Jesus Christ will come to the world a second time to judge with justice, and will also kill the Antichrist (al-Dajjāl) (Bukhārī, 1981, p. 244; Muslim, 1955, p. 6). Nursi's interpretation of these hadith is as follows: Denying God will spread via the materialist philosophy at the end of time. At that point, Christianity will join Islam. As a result, Muslims and 
Christians will be able to defeat the atheistic current (Nursi, 2001, p. 78). It is clear from the information above that Nursi identifies religious basis for Muslim-Christian cooperation.

In this context, Nursi can also be considered to be "inclusivist". He is committed to the truth of Islam as revealed in the Qur'an and the life of the prophet Muhammad. However, he admits that other traditions have a partial insight into the truth. Inclusivism is a space that protects both commitment to truth and toleration (Markham, 2009, p. 64).

Secondly, Nursi believes that the enemy of human happiness and ethical uprightness is unbelief, irreligion. In seeking to affirm a Divinely-guided way of life in the modern period, Muslims can find their friends in those Christians who are committed to following the teachings of Jesus and seek to live according to the truth (Michel, 2003, p. 28). In this context, he states that,

Believers should now unite, not only with their Muslim fellow-believers, but with truly religious and pious Christians, disregarding questions of dispute and not arguing over them, for absolute disbelief is on the attack. (Nursi, 2009, I/p. 202)

Moreover, "religion-less" spirituality has been significantly increasing among secular people in the West. For them, spirituality offers an alternative to conservative religion. Talk of spirituality separate from religion is so popular and seems very liberating and helpful. As many Christian theologians underline, Nursi maintains that spirituality is very important. However, it must be grounded in the revelation of God. Our experience of God must be located in tradition. In other words, people need to locate their spirituality in a valid interpretation of faith. He goes on to say that the text and the community are fundamental for an appropriate interpretation of a religious experience. We can reasonably conclude that Nursi disagrees with those who want to separate spirituality from religion (Markham, 2009, pp. 79-93; Mattson, 2014). In this context, it may be said that Muslims and Christians can collaborate on this purpose.

\section{Culture of Coexistence and Peace in Islamic Tradition}

It is important to note that despite occasional sectarian conflicts, traditional Muslim societies succeeded in creating a stable and peaceful habitat in which both Muslim and non-Muslim members of the community contributed to the development of a world civilisation in such diverse fields as arts, sciences, trade and architecture. The notion of cultural and religious coexistence that came about in this milieu was not simply based on the temporary absence of conflict and confrontation between Islamic and non-Islamic elements. Its positive character was developed and sustained by the inclusivist attitude of Muslims towards other cultures and religious traditions. There are a great number of examples in the history of Islam to show the cultural ecumenism of Muslim societies. Muslim philosophers' approach to pre-Islamic traditions of learning can be a good example. For the Muslim scholars and scientists, the search for truth was both within and beyond religious boundaries. Moreover, the Islamic concept of cultural pluralism was extended to practically all minorities living in the lands of Islam. The experience of convivencia among Jews, Christians, and Muslims in Andalusia was an outcome of the Islamic concept of cultural inclusivism. It should be emphasised that such modes of cultural coexistence would have been impossible without the acceptance of the diversity of cultures and societies as part of human existence. The Qur'an mentions this issue in its various verses. Working towards a common good is made dependent on the existence of different communities (Q. 5:48, Q. 11:118). The Qur'an also points out the civic responsibility of "knowing one another" (Q. 49:13) (Kalin, 2013, pp. 242-248). 
The examples above from the history of Islamic culture indicate that both the Islamic intellectual tradition and Muslim societies have thought peace as a cross-cultural and inter-communal value. Ibrahim Kalin argues that the Islamic tradition has expressed a concept of peace that extends from metaphysics and cosmology to law and culture. It cannot be possibly understood the experience of Muslim societies with the cultural and religious other(s) without considering these elements. Today, there is an emerging consensus on supporting peace as a value in itself, regardless of the political state of Muslim countries and communities in the world. Muslim communities can no longer speak to issues of conflict and violence without developing a proper ethics of peace. To sum up, achieving and establishing a culture of peace is an urgent need for Muslim communities in their inter-communal relations and their relations with other communities (Kalin, 2013, pp. 248-249).

In conclusion, it should be noted here that the argument of this paper is that there is the need for establishing culture of coexistence, which practised before within a religious tradition such as Islamic tradition for many centuries in the history. Through achieving a culture of coexistence and peace, most conflicts can be resolved. Achieving peace among different communities, establishing bridges via dialogue, reducing hostility and conflicts, and developing experience of peaceful coexistence are of particular significance in today's pluralist world. Members of each religious community can come together and collaborate for shared human values.

\section{References}

Abdel Haleem, M. A. S. (2004). The Qur'an. New York: Oxford University Press.

Albayrak, I. (2008). The People of the Book in the Qur'an. Journal of Islamic Studies, 47,(3), 301-325.

Al-Rāzī, F. (1981). Mafātīḥal-ghayb. Beirut: Dār al-Fikr.

Ayoub, M. (2007). A Muslim view of Christianity: Essays on dialogue. A. Omar. Irfan, (Ed.). Maryknoll, NY : Orbis Books.

Baljon, J. M. S. (1961). Modern Muslim Koran interpretation. Leiden: Brill.

Bukhārī. (1981). Sahīhal-Bukhārī. Damascus: Dār al-Qalam.

Çoruh, H. (2012). Friendship between Muslims and the People of the Book in the Quran with Special Reference to Q 5. 51. Islam and Christian-Muslim Relations, 23(4), 505-513.

Crow, K. D. (2013). The concept of peace/security (Salm) in Islam. In P. G. b. Muhammad, I. Kalin, and M. H. Kamali (Eds.), War and peace in Islam (pp. 250-268). Cambridge: MABDA.

Gülen, F. (2014). Kur'an'da Yahudiler ve Hiristiyanlar. Fasıldan Fasıla 4. Retrieved from http://tr.fgulen.com

Heck, P. L. (2004). Jihad revisited. The Journal of Religious Ethics, 32(1), 95-128.

Kalin, I. (2013). Islam and peace: A survey of the sources of peace in the Islamic tradition. In P. G. b. Muhammad, I. Kalin, and M. H. Kamali (Eds.), War and peace in Islam (pp. 217-249). Cambridge: MABDA.

Karaman, H., Çağrıcı, M., Dönmez, İ.K., Gümüş, S. (2007). Kur'an Yolu Türkçe Meāl ve Tefsir. Ankara: DİB Yayınları.

Kurucan, E. (2013). Jihad what is it and what is it not? Fountain Magazine, 96. Retrieved from www.fountainmagazine.com

Markham, I. S. (2009). Engaging with Bediuzzaman Said Nursi a model of interfaith dialogue. USA: Ashgate.

Mattson, I. (2014). The relevance of the Abrahamic traditions to an increasingly "spiritual not religious" American society. Retrieved from http://vimeo.com/34610289

Michel, T. (2003). Reflections on Said Nursi's views on Muslim-Christian understanding. Istanbul: Soz Basim.

Muslim. (1955). Sahīh Muslim. Cairo: Maktabat al-Halabī.

Nielsen, J. (2003). Contemporary discussion on religious minorities in Islam. Islam and Christian-Muslim Relations, 14(3), 325-335.

Nursi, S. (2001). Letters. (Ş. Vahide, Trans.). Istanbul: Sözler Yay.

Nursi, S. (2009). Emirdă̆ Lāhikası. Istanbul: Şahdamar Yayınları.

Özel, A. (1993). Cihad. In Heyet (Ed.), Diyanet İslam Ansiklopedisi (7/527-531). İstanbul: Diyanet Vakf1.

Rahman, F. (2009). Major themes of the Qur'an. Chicago: University of Chicago Press.

Saeed, A. (2008). The Qur'an: An introduction. London: Taylor \& Francis e-Library. 
Turner, C. (2013). The Qur'an revealed: A critical analysis of Said Nursi's epistles of light. Berlin: Gerlach Press.

Ünal, A. (2008). The Qur'ān with annotated interpretation in modern English. New Jersey: The Light.

Vahide, Ş. (2005). Islam in modern Turkey: An intellectual biography of Bediüzzaman Said Nursi. Albany: State University of New York Press.

Y1lmaz, Ö. (2008). “Öteki”ile diyalojik ilişkinin gereği. Islamic University of Europe-Journal of Islamic Research, 1, 137-145. 